\title{
The ileum of the sheep as a site of protein digestion
}

\author{
By D. BEN-GHEDALIA, H. TAGARI AND A. BONDI \\ Department of Animal Nutrition, The Hebrew University, \\ Faculty of Agriculture, Rehovot, Israel
}

(Received 20 October 1975 - Accepted I 5 March 1976)

\begin{abstract}
1. In order to study the ability of the ileum of the sheep to digest and absorb protein, casein or gluten were infused into the intestine of rams through cannulas inserted at distances of $0.05,7,9$ and $15 \mathrm{~m}$ from the pylorus. Amounts of casein or gluten containing $10-20 \mathrm{~g}$ nitrogen were infused during $24 \mathrm{~h}$, in animals given a low-N diet.

2. $\mathrm{N}$ balance was negative during the preliminary period when no infusion was given; infusion of casein or gluten increased the daily $\mathrm{N}$ retention to $5^{-1} 5 \mathrm{~g}$.

3. Infusion of proteins into the intestine did not induce an increased activity of pancreatic proteases in digesta withdrawn from the lower part of the intestine.

4. The increased $N$ retention after the infusion of proteins into the lower part of the intestine indicates a considerable capacity of this section of the intestine to digest and absorb proteins.
\end{abstract}

The localization of protein digestion along the gut has been studied extensively in man (Nixon \& Mawer, 1970) and chicks (Bird, I968).

However, there is little information concerning the relative contribution of different regions of the sheep's small intestine to protein digestion. Whereas Kay (1969) suggested that segmental specialization of the sheep's intestine associated with protein digestion does not exist, Ben-Ghedalia, Tagari, Bondi \& Tadmor (1974) reported that the middle one-third of the small intestine was the main site for protein digestion and absorption. In the latter study, the activities of pancreatic proteases were found to be markedly reduced as the digesta flowed along the lower part of the small intestine. Whether consequently or not, no apparent protein digestion or absorption was found in the last $10 \mathrm{~m}$ of the small intestine. Furthermore, a considerable amount of proteinnitrogen $(7.5 \mathrm{~g})$, passed daily to the terminal ileum, while the $\mathrm{N}$ ingested in food amounted to $\mathrm{I} 8.8 \mathrm{~g} / \mathrm{d}$. In view of these findings, the ability of the sheep to digest and absorb protein along the last $10 \mathrm{~m}$ of the small intestine might be questioned. The present study was designed to determine whether this ability does in fact exist, and if not, whether digestion or absorption is the limiting factor.

In order to study the ability of the ileum of sheep to digest and absorb protein, casein, wheat gluten or casein hydrolysate was infused into the lower part of the intestine of cannulated rams. The high values for $\mathrm{N}$ digestibility and retention indicate considerable ability of the ileum to both digest protein and absorb the digested products. 


\section{Table $\mathrm{x}$. The composition $(\mathrm{g} / \mathrm{kg})$ of the semi-purified diets given during Expts I and 2}

$\begin{array}{lcc}\quad \text { Ingredient } & \text { Expt I } & \text { Expt 2 } \\ \text { Starch } & 570 & 267 \\ \text { Cottonseed hulls } & 400 & 300 \\ \text { Citrus pulp } & - & 400 \\ \text { Sodium chloride } & 10 & 10 \\ \text { Dicalcium phosphate } & 10 & 10 \\ \text { Calcium carbonate } & 7 & 10 \\ \text { Mineral mixture* } & 3 & 3 \\ \text { Vitamin mixture }{ }_{\text {Nitrogen content }} & & 5.07\end{array}$

- A commercial mineral mixture used as an additive in concentrates for calf fattening (Folkman \& Kofler Ltd, Petach Tikva, Israel).

+ Supplying $400 \mu \mathrm{g}$ retinol equivalent, $20 \mu \mathrm{g}$ cholecalciferol equivalent and $13.4 \mathrm{mg} \alpha$-tocopherol $/ \mathrm{kg}$ diet.

EXPERIMENTAL

Expt I

Two 2-year-old, 55-6o kg rams were given four treatments in four successive treatment periods. One animal was equipped with a $T$-shaped intestinal cannula at $7 \mathrm{~m}$ from the pylorus, the second was cannulated at $15 \mathrm{~m}$ from the pylorus. The cannulation procedures were as described previously (Ben-Ghedalia et al. 1974).

Treatment period $\mathrm{I}$. The diet consisted of $400 \mathrm{~g}$ vetch hay (Vicia sativa L.) (N content $20.8 \mathrm{~g} / \mathrm{kg}$ ) and $600 \mathrm{~g}$ commercial concentrate mixture (N content $20.5 \mathrm{~g} / \mathrm{kg}$ )/d as given by Ben-Ghedalia et al. (1974). This diet was designed to produce a positive $\mathrm{N}$ balance (positive control diet). During this treatment period and throughout the experiment, the food was given in equal amounts twice daily at 07.30 and 19.30 hours. After an adaptation period of $30 \mathrm{~d}$, a $\mathrm{N}$ balance experiment lasting $5 \mathrm{~d}$ was carried out. Details of procedures used in $\mathrm{N}$ balance experiments have been described (Tagari, 1969).

Treatment period 2. During this treatment period, the rams received a $\mathrm{N}$-deficient diet consisting of a semi-synthetic mixture ('Table I) $(3.07 \mathrm{~g} \mathrm{~N} / \mathrm{kg}$ ); ram no. I was offered $450 \mathrm{~g} / \mathrm{d}$ and ram no. $2500 \mathrm{~g} / \mathrm{d}$. In addition, $800 \mathrm{~g}$ cottonseed hulls $(8.64 \mathrm{~g}$ $\mathrm{N} / \mathrm{kg}$ )/d were offered to each ram. This ration (negative control diet) was considered to induce a negative $\mathrm{N}$ balance. The object of this treatment was to adjust the animals to a low body $\mathrm{N}$ status, which would serve as a baseline from which their capacity to digest and absorb a protein or its hydrolysate infused into the distal part of the small intestine could be assessed. Feeding and $\mathrm{N}$ balance procedures were as used during treatment period $\mathrm{I}$. This treatment period consisted of a $5 \mathrm{~d}$ gradual diet change, followed by a ro $\mathrm{d}$ adaptation period and $5 \mathrm{~d}$ collection period.

Treatment period 3. The negative control diet was continued during this period. Casein hydrolysate (acid-, salt- and vitamin-free; Nutritional Biochemicals Corporation, Cleveland, Ohio, USA) was infused into ram no. I at the $7 \mathrm{~m}$ site and into ram no. 2 at the $15 \mathrm{~m}$ site. Casein hydrolysate $(63 \mathrm{~g})$ was dissolved in $700 \mathrm{ml}$ distilled water together with $0.63 \mathrm{~g}$ tryptophan, and the mixture was infused using a peristaltic 
pump (Type RZG; H. H. Heidolph, Schwabach, W. Germany), 20-24 h/d for $7 \mathrm{~d}$. Faeces and urine collections began on the third day of infusion.

Treatment period 4 . The sheep continued to receive the negative control diet. Infusion of intact casein was begun I week from the end of the casein-hydrolysate infusion. Casein ( $70 \mathrm{~g}$; non-protein- $\mathrm{N}$-free) was dissolved in $700 \mathrm{ml} 0.028 \mathrm{M}$-disodium hydrogen phosphate as described by Egan \& Moir (1965) and its $\mathrm{pH}$ was adjusted to simulate the $\mathrm{pH}$ of digesta found at the infusion sites. The experimental procedures were as in treatment period 3 .

\section{Expt 2}

The object of this experiment was to study the digestive potential of the distal part of the sheep's small intestine when greater amounts of protein (casein or gluten) than those used in Expt I were infused. Four rams, I-2 years old and weighing about $50 \mathrm{~kg}$, were used. Two of them (rams nos. 3 and 4) were cannulated at the duodenum ( $0.05 \mathrm{~m}$ from the pylorus), the third (ram no. 5) and fourth (ram no. 2) were equipped with $T$-shaped cannulas at 9 and $15 \mathrm{~m}$ distance from the pylorus respectively.

The animals were offered $900 \mathrm{~g}$ negative control diet/d (Table $\mathrm{I}$ ), supplying $4.6 \mathrm{~g}$ $\mathrm{N} / \mathrm{d}$, as the only feeding-stuff throughout the experiment. The composition of the diet was modified from that used in Expt $I$ by incorporating dried citrus pulp (Table I), in order to make it more palatable. The feeding procedure was as described in Expt 1 except that, before the meals, chromic oxide ( $\mathrm{g}$ ) impregnated into paper was supplied to rams nos. 2 and 5 , to enable measurements of the rate of flow of the digesta at the cannulation sites.

$\mathrm{N}$ balance was determined as in Expt $\mathrm{I}$ and, in addition, pancreatic protease activities in digesta sampled from rams nos. 2 and 5 were determined. Six digesta samples/d were withdrawn, beginning $\mathrm{I} \mathrm{h}$ after the morning meal, at $\mathrm{I} \cdot 5 \mathrm{~h}$ intervals on the Ist, $3^{\text {rd }}$ and $5^{\text {th }}$ day of each period. The infusion of protein was stopped ro min before each sampling.

Treatment period $\mathrm{I}$. The negative control diet was fed for $20 \mathrm{~d}$ of adaptation and $5 \mathrm{~d}$ of $\mathrm{N}$ balance; samples of digesta were taken during the balance experiment.

Treatment period 2. During this treatment period $\mathrm{I} 40 \mathrm{~g}$ casein/d dissolved in $800 \mathrm{ml}$ $0.028 \mathrm{M}-\mathrm{Na}_{2} \mathrm{HPO}_{4}$ were infused for $7 \mathrm{~d}$. On the Ist day, digesta sampling was begun; faeces and urine collections were started on the $3^{\text {rd }}$ day of infusion.

Treatment period 3 . The infusion consisted of $\mathrm{I} 80 \mathrm{~g}$ wheat gluten $(796 \mathrm{~g}$ protein $/ \mathrm{kg}$ ) dispersed in $1600 \mathrm{ml} 0.02 \mathrm{M}$-hydrochloric acid. This gave a suspension at $\mathrm{pH} 3$ which was suitable for infusion into the duodenum. For infusion at the 9 and $15 \mathrm{~m}$ sites, $0.05 \mathrm{M}$-sodium hydroxide was simultaneously infused at a rate calibrated to adjust the $\mathrm{pH}$ of the gluten infusate to that of the digesta. Further experimental steps were as described for treatment period 2.

\section{Analytical methods}

Total $\mathrm{N}$ in diets, faeces and urine was determined by the Kjeldahl technique. Trypsin (EC 3.4.4.4), chymotrypsin A (EC 3.4.4.5) and carboxypeptidase A (EC $3 \cdot 4 \cdot 2.1$ ) activities in digesta were measured by the methods used by Ben-Ghedalia et al. (1974). $\mathrm{Cr}_{2} \mathrm{O}_{3}$ was determined by the method of Stevenson \& de Langen (1960). 
Table 2. Expt $\mathrm{r}$. Nitrogen digestibilities and retentions of two rams cannulated at intestinal sites 7 or $15 \mathrm{~m}$ distal to the pylorus, and given successively (I) a $N$-sufficient diet* (positive control diet), (2) a $N$-deficient diet* (negative control diet (NCD)), (3) NCD +intestinal infusions of $6_{3} g$ casein hydrolysate into the 7 or $\mathrm{I}_{5} \mathrm{~m}$ sites, (4) NCD+intestinal infusions of $70 \mathrm{~g}$ intact casein into the 7 or $15 \mathrm{~m}$ sites

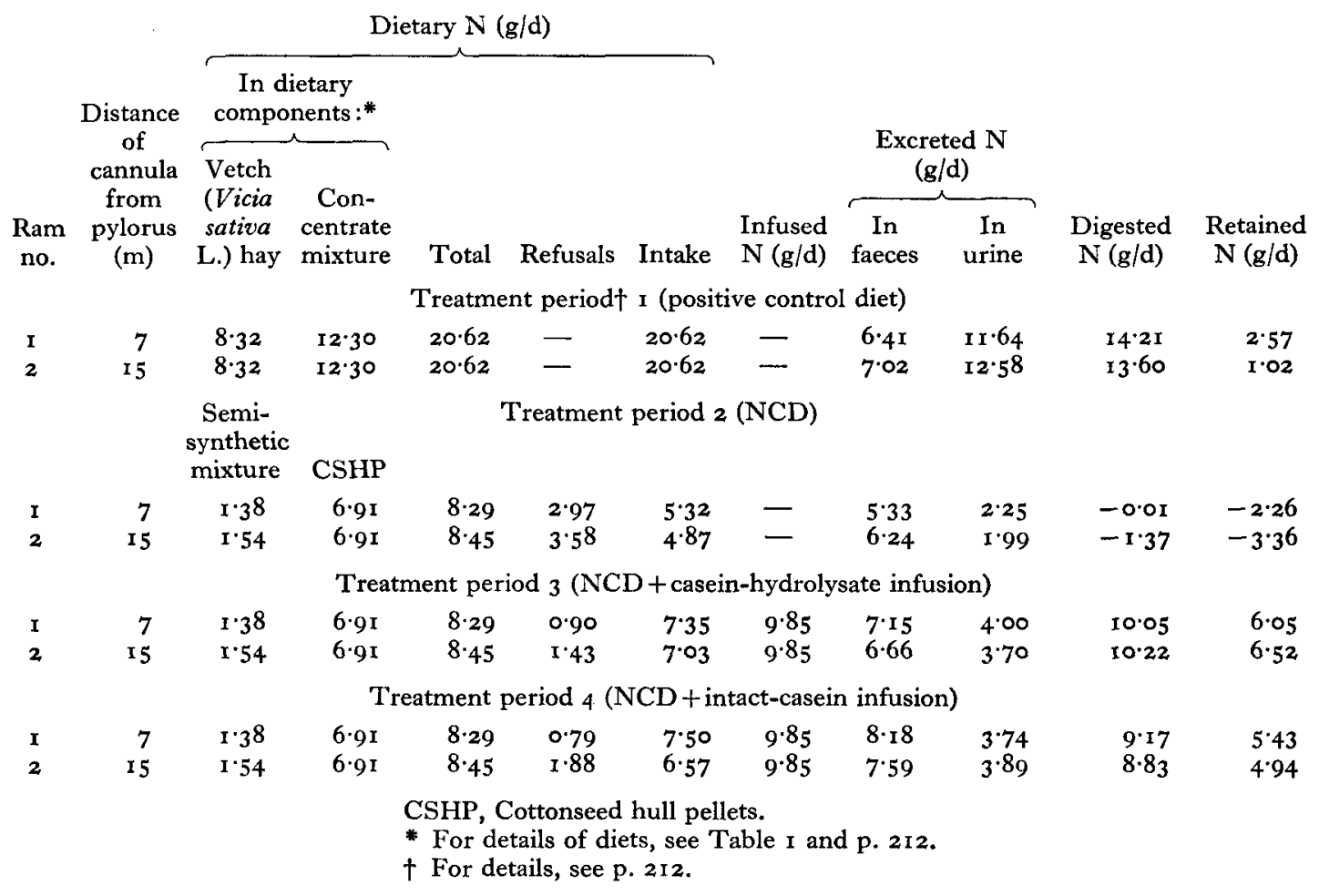

\section{RESULTS}

\section{Expt I}

Values for $\mathrm{N}$ digestibility and retention for the positive and negative control diets are given in Table 2 (treatment periods $\mathrm{I}$ and 2 respectively). When the positive control diet (400 g vetch hay and $600 \mathrm{~g}$ concentrate/d) was fed, a positive $\mathrm{N}$ retention was obtained with both rams. On the other hand, when the negative control diet was fed, the $\mathrm{N}$ retention was negative. $\mathrm{N}$ balance results for the infusion treatments are given in Table 2 (treatment periods 3 and 4 ). During the protein infusions, food intake was improved and amounts of refusals were reduced. The faecal $\mathrm{N}$ excreted daily by both rams given infusions of the casein hydrolysate and intact casein resembled quantitatively the amounts of $\mathrm{N}$ ingested orally. Considering that the apparent $\mathrm{N}$ digestion of the negative control diet was close to $\mathrm{O}$ (see Table 2), it appears that the casein hydrolysate and intact casein infused into the intestine at 7 and $15 \mathrm{~m}$ from the pylorus were largely absorbed. The considerable $N$ retentions $\left(5^{\circ} 0-6.5 \mathrm{~g} / \mathrm{d}\right)$ obtained in these experiments support this assumption. 
Table 3. Expt 2. Nitrogen digestibilities and retentions of rams cannulated at intestinal sites $0.05,9$ and $15 \mathrm{~m}$ distal to the pylorus, and given successively (I) a $\mathrm{N}$-deficient diet* (negative control diet $(N C D)$ ), (2) NCD + intestinal infusions of $140 \mathrm{~g}$ intact casein into the 0.05 , 9 or $15 \mathrm{~m}$ sites, (3) NCD+intestinal infusions of $180 \mathrm{~g}$ wheat gluten into the 0.05 , 9 or $15 m$ sites

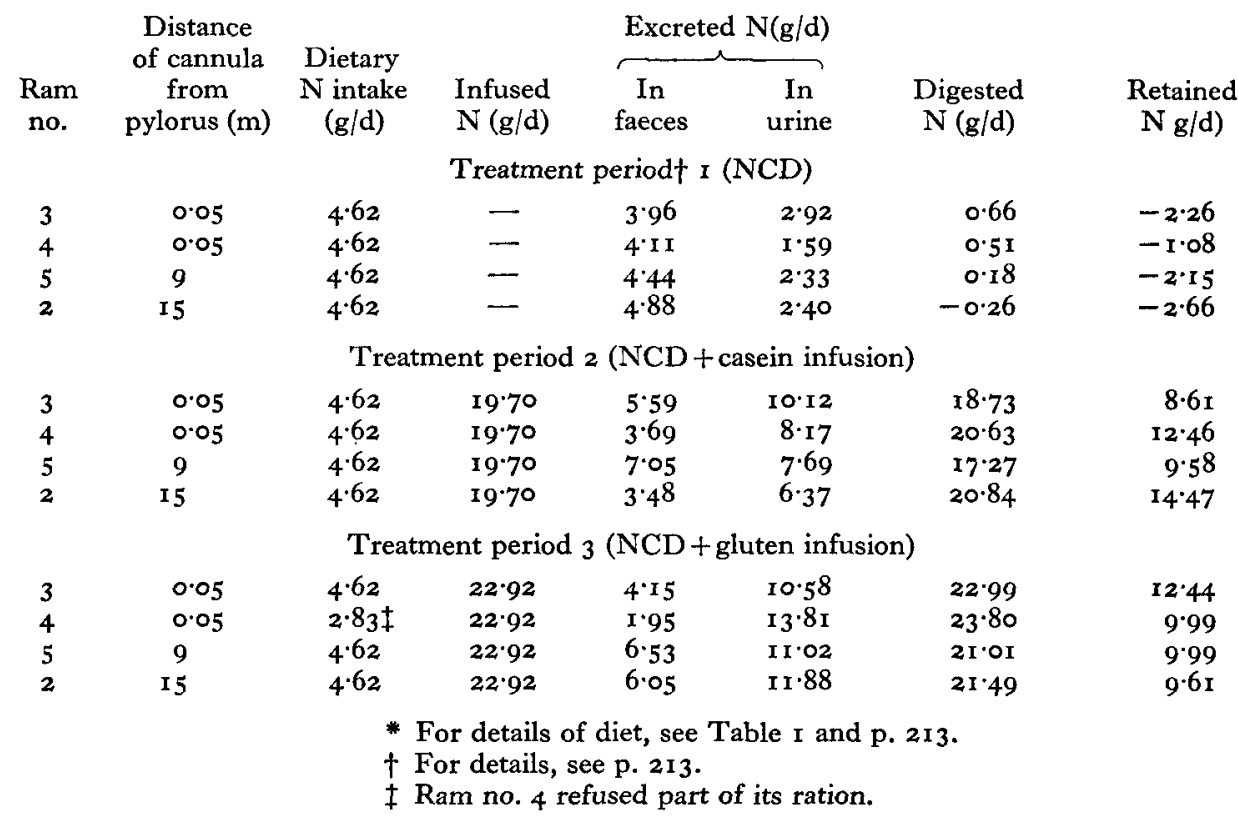

\section{Expt 2}

$\mathrm{N}$ balance results are given in Table 3. As in Expt $\mathrm{I}$, the sheep given the negative control diet were in negative $\mathrm{N}$ retention and would have lost substantial amounts of body $\mathrm{N}$ by the end of the $25 \mathrm{~d}$ preliminary period. In confirmation of Expt $\mathrm{I}$, casein infused at 9 or $15 \mathrm{~m}$ distal to the pylorus was as well digested and absorbed as when infused into the duodenum. Doubling the amount of the infused casein did not adversely affect its digestion and absorption along the distal part of the small intestine (Table 3, treatment period 2 , cf. Table 2, treatment period 4). The very high $\mathrm{N}$ retention of the four rams, irrespective of the infusion sites, indicated that casein, even when infused in considerable amounts was well digested and absorbed as amino acid-N.

The results obtained with the gluten infusion are given in Table 3 (treatment period 3 ). Gluten infused at 9 or $15 \mathrm{~m}$ distal to the pylorus was absorbed to almost the same extent as gluten infused into the duodenum. Ram no. 4, infused at $0.05 \mathrm{~m}$ from pylorus, refused part of its ration and this is reflected in the lower faecal $\mathrm{N}$ excretion. Again the very high $\mathrm{N}$ retentions can be explained only by digestion and amino acid- $\mathrm{N}$ absorption from the intestine.

The proteolytic activities of intestinal digesta, both in terms of specific activities 
Table 4. Expt 2. Specific ( $\mu$ mol/min per $m l$ ) and total activities (specific activity $\times$ daily flow; mmol/min) of carboxypeptidase $A$ (EC 3.4.2. $\mathrm{x}$ ), trypsin (EC 3.4.4.4) and chymotrypsin $A$ ( $\mathrm{EC}_{3.4 .4 .5)}$ in digesta sampled at intestinal sites 9 or $15 \mathrm{~m}$ distal to the pylorus in two rams given successively $(\mathrm{I})$ a $N$-deficient diet* (negative control diet $(N C D)),(2) N C D+$ intestinal infusions of $140 \mathrm{~g}$ intact casein into the 9 or $15 \mathrm{~m}$ sites, (3) $N C D+$ intestinal infusions of $180 \mathrm{~g}$ wheat gluten into the 9 or $15 m$ sites

(Mean values for three determinations/ram)

\begin{tabular}{|c|c|c|c|c|c|c|c|c|}
\hline \multirow[b]{3}{*}{$\begin{array}{c}\text { Ram } \\
\text { no. }\end{array}$} & \multirow{3}{*}{$\begin{array}{l}\text { Distance of } \\
\text { cannula } \\
\text { from } \\
\text { pylorus (m) }\end{array}$} & \multirow{3}{*}{$\begin{array}{c}\text { Treatment } \\
\text { period } t\end{array}$} & \multicolumn{6}{|c|}{ Enzyme activities } \\
\hline & & & \multicolumn{2}{|c|}{ Carboxypeptidase A } & \multicolumn{2}{|c|}{ Trypsin } & \multicolumn{2}{|c|}{ Chymotrypsin A } \\
\hline & & & $\overparen{\text { Specific }}$ & Total & Specific & Total & Specific & Total \\
\hline \multirow[t]{3}{*}{5} & 9 & $\stackrel{\text { I }}{(\mathrm{NCD})}$ & $29 \cdot 6$ & I94 & $23 \cdot 6$ & r 55 & 139 & 9 I 3 \\
\hline & & $\begin{array}{c}2 \\
(\mathrm{NCD}+\text { casein } \\
\text { infusion })\end{array}$ & $2 I \cdot 6$ & 127 & $24 \cdot 9$ & I 49 & 144 & 879 \\
\hline & & $\begin{array}{c}3 \\
(\mathrm{NCD}+\text { gluten } \\
\text { infusion) }\end{array}$ & $27 \cdot 5$ & 246 & $16 \cdot 0$ & 142 & $88 \cdot 0$ & 779 \\
\hline \multirow[t]{6}{*}{2} & 15 & $\begin{array}{c}\mathrm{I} \\
(\mathrm{NCD})\end{array}$ & $17 \cdot 9$ & 89 & $9 \cdot 0$ & $45 \cdot 4$ & $65 \cdot 6$ & $33 \mathrm{r}$ \\
\hline & & 2 & $17 \cdot 9$ & 65 & II'2 & $39 \cdot 8$ & $35^{\cdot 2}$ & 125 \\
\hline & & $\begin{array}{c}\text { (NCD + casein } \\
\text { infusion) }\end{array}$ & & & & & & \\
\hline & & 3 & $36 \cdot 3$ & 150 & $13 \cdot 9$ & $56 \cdot 9$ & $57 \cdot 9$ & 237 \\
\hline & & $\begin{array}{c}\text { (NCD + gluten } \\
\text { infusion) }\end{array}$ & & & & & & \\
\hline & & SEM & $2 \cdot 4$ & - & $I \cdot 5$ & - & $10 \cdot 2$ & \\
\hline
\end{tabular}

and total activities (specific activity $\times$ daily flow of digesta passing the cannulas at 9 and $15 \mathrm{~m}$ distal to the pylorus) are given in Table 4 . It appeared that total activities of trypsin and chymotrypsin A were not positively affected by protein infusion into the intestine; only gluten infusions, but not those of casein, may have caused an increase in total activities of carboxypeptidase A.

\section{DISCUSSION}

The primary purpose of the present study was to determine whether absorptive or digestive limitations or both prevail in the lower small intestine of the sheep. The results of this work indicated that casein hydrolysate, intact casein and gluten infused into the lower sites of the intestine were well absorbed and resulted in positive $\mathrm{N}$ retention. This utilization of protein infusates revealed by good $\mathrm{N}$ retention values can be explained only by proteolysis and absorption of amino acids occurring in the lower parts of the intestine. 
Apparently, the proteolytic breakdown of casein and gluten infused into the lower intestine was not disturbed by the complete absence of pepsin. Orally ingested proteins are attacked by pepsin which continues to act in the weakly acid medium of the upper intestine (Ben-Ghedalia, 1973). In the instance of the gluten infusion neither the absence of pepsin nor even the insolubility of gluten in the alkaline medium prevented proteolysis.

It could be expected that the extensive digestion of protein infused into the lower intestine would be associated with an enhanced activity of pancreatic proteases. In fact, increasing the protein content of diets given to simple-stomached animals is known to induce enhanced activity of pancreatic proteases (Snook, 1974). In the present study, however, most of the proteolytic activities measured in the lower sections of the intestine were not positively affected by protein infusions into the intestine. The conclusion drawn by Snook (1973) from findings for simple-stomached animals that protease production by the pancreas far exceeds the requirements of animals in most situations, certainly seems to be valid for ruminants with respect to their digestive capacity towards infused proteins.

The ability of the lower part of the intestine to digest and absorb proteins was indicated by the results of the present work. The finding in our previous study (Ben-Ghedalia et al. 1974) of a very low net absorption in the distal sections of the intestine must not be a necessary consequence of digestive and absorptive limitations; in these earlier experiments proteins were supplied to sheep at maintenance level, and under these circumstances all proteins susceptible to proteolytic breakdown were digested and absorbed in the upper sections of the gastrointestinal tract and apparently little or no available $\alpha$-amino $\mathrm{N}$ reached the lower intestine.

\section{REFERENCES}

Ben-Ghedalia, D. (1973). Protein digestion in different sections of the gastrointestinal tract of the sheep. PhD Thesis, The Hebrew University of Jerusalem.

Ben-Ghedalia, D., Tagari, H., Bondi, A. \& Tadmor, A. (1974). Br. F. Nutr. 3r, r25.

Bird, F. H. (1968). Fedn Proc. Fedn Am. Socs exp. Biol. 27, I 94.

Egan, A. R. \& Moir, R. J. (1965). Aust. F. agric. Res. 16, 437.

Kay, R. N. B. (1969). Proc. Nutr. Soc. 28, 140.

Nixon, S. E. \& Mawer, G. E. (1970). Br. Y. Nutr. 24, 227.

Snook, J. T. (1973). Wld Rev. Nutr. Diet. 18, 121.

Snook, J. T. (1974). Fedn Proc. Fedn Am. Socs exp. Biol. 33, 88.

Stevenson, A. E. \& de Langen, H. (1960). N.Z. Fl agric. Res. 3, 3 14.

Tagari, H. (1969). Br. F. Nutr. 23, 455 . 